\title{
Development of a low cost household bone-char defluoridation filter
}

\author{
Boris Merlain DJOUSSE KANOUO*, Mathias FRU FONTEH and \\ Steve PINDJOU NGAMBO
}

\begin{abstract}
Water Management Research Unit, Department of Rural Engineering, Faculty of Agronomy and Agricultural Sciences, University of Dschang, P.O.Box 222, Dschang, Cameroun.

*Corresponding author; E-mail: djoussemerlain@gmail.com; Tel: +237 699727 021;
\end{abstract}

ORCID iD: 0000-0003-4606-3122

\begin{abstract}
Regular intake of drinking water containing fluoride above permissible levels $\left(>1.5 \mathrm{mgl}^{-1}\right)$ is responsible for dental and skeletal fluorosis. The objective of this study was to develop a low cost and efficient water defluoridation filter using local materials. The filter frame was made from Polyvinyl chloride pipe of $125 \mathrm{~mm}$ diameter and $1 \mathrm{~m}$ height, with a useful filtration volume of 9.551 . The filtration layer consisted of a sequence of three strata: gravel, bone-char and sand, giving a total weight of $15 \mathrm{~kg}$. Based on the concentration of fluoride in drinking water in parts of northern Cameroon, three different fluoride ion concentrations $\left(10 \mathrm{mgl}^{-1}, 20\right.$ $\mathrm{mgl}^{-1}$ and $30 \mathrm{mgl}^{-1}$ ) were prepared in the laboratory using distilled water and allowed to flow through the filter at the rate of $3.33 \mathrm{lh}^{-1}$. High fluoride uptake capacity was observed (94.8\% to $99.1 \%$ ), depicting the suitability of the filter in defluoridation. The constructed filter costed about 17 US\$. Based on these results, the filter can be recommended as an appropriate technology to mitigate fluoride health hazards problems in low income families. Although the estimated replacement frequency of biochar was three months, further research is required to optimize the point of use system performances.
\end{abstract}

(C) 2020 International Formulae Group. All rights reserved.

Keywords: Bone-char, water filter, fluoride.

\section{INTRODUCTION}

Throughout history, groundwater has always been used as a source of drinking water. Today, more than half of the world's population depends on it to survive. It constitutes $97 \%$ of freshwater and for many communities, is the only economically viable option for drinking water supply. Groundwater is, in general, free from organic and microbiological pollution. However, it might contain elements which, beyond a certain concentration, can considerably compromise its quality. One of these element is $\mathrm{F}^{-}$(Bhatnagar et al., 2011), which could be of natural (geogenic) or anthropogenic source (Grützmacher et al., 2013). Besides its prophylactic role in the human organism (Goyit et al., 2018), long-term accumulation of $\mathrm{F}^{-}$ions in the body produces adverse effects such as the destruction of teeth enamel (fluorosis), the development of diseases such as osteoporosis, cardiac, psychological and even genetic damage (Yang and Dluhy, 2002 ; Ayoob and Gupta, 2006). Fluoride is therefore often described as a 'double-edged sword' as inadequate ingestion is associated with dental caries, whereas 
excessive intake leads to dental, skeletal and soft tissue fluorosis which has no cure (Swarnakar et al., 2007). Many countries have waters with a $\mathrm{F}^{-}$concentration well above the world health organisation recommended value of $1.5 \mathrm{mg} \mathrm{l}^{-1}$ (Fawell et al., 2006). Excessive concentrations of $\mathrm{F}^{-}$have been reported in groundwater in more than 27 developed countries including England, France, Italy, USA and developing countries, including India. In India, about 19 states face an acute fluorosis problem due to excessive $\mathrm{F}^{-}$ concentration in waters (Meenakshi and Maheshwari, 2006). High $\mathrm{F}^{-}$concentration in drinking water is therefore a global problem.

In the northern part of Cameroon, the average rainfall decreased from $700 \mathrm{~mm} /$ year before 1970 to $500 \mathrm{~mm} / \mathrm{year}$ in recent years (L'Hôte et al., 2002). This diminishing water resources following the phenomenon of climate change exacerbates drinking water shortage in the locality. Studies carried out in this region, particularly in the Mayo Tsanaga watershed (MTW), revealed high concentrations of $\mathrm{F}^{-}\left(>16 \mathrm{mgl}^{-1}\right)$ in $27 \%$ of underground water sources. Also, cases of dental fluorosis have already been identified within this river basin (Fantong et al., 2010). This contamination of groundwater with $\mathrm{F}^{-}$, primarily of geological origin, is linked to the dissolution of fluorine-rich minerals in granites, common rock in the subsoil of this watershed (Fantong et al., 2008). This $\mathrm{F}^{-}$ concentration value is far above the range of 0.6 to $1.5 \mathrm{mgl}^{-1}$ recommended for drinking water by the food and agricultural organisation (FAO) or by the national upper limit value of $0.7 \mathrm{mgl}^{-1}$. In Mayo Tsanaga river basin, it is estimated that about 500,000 people chiefly rely on highly fluoridated groundwater for their feed. Fortunately, Cameroon has not yet experienced a real crisis related to the presence of excess $\mathrm{F}^{-}$in drinking water, however it is actually worth exploring potential local solutions for this population before the worst happens.

Several methods have been developed for the treatment of fluoridated waters (Ghosh, 2016); These are grouped into physicochemical or membrane processes (electrodialysis, reverse osmosis) and chemical processes (ion exchange, adsorption, precipitation). For filters which chemical process is based on adsorption, the sorption reaction can be considered to occur in three distinct phases (Nasr, 2014). An initial phase, during which the sorption reaction is very rapid, due to specific physicochemical (or affinity) interactions with the surface of the adsorbent. During this phase, $\mathrm{F}^{-}$ions removal rate is rapid (less than $30 \mathrm{~min}$ ). Throughout the second phase, there is migration of $\mathrm{F}^{-}$ions from the surface to the internal pores of the adsorbent. Within the last phase, that is beyond $60 \mathrm{~min}$, the retention rate of $\mathrm{F}^{-}$ions remains constant, indicating the level of equilibrium and saturation of sorption sites. Fan et al. (2003) also found that the time required for adsorption to reach equilibrium is 60 minutes with hydroxyapatite, calcite, quartz and quartz activated by ferric ions as substrate.

The $\mathrm{pH}$ of the solution to be filtered can influence the efficiency of the filtration. Nasr (2014) observed that when the $\mathrm{pH}$ of the solution varies between 4.5 and 7.5 , the retention rate of $\mathrm{F}^{-}$ions is almost constant and high, It becomes weak when the $\mathrm{pH}$ increases to 10.5 . This is because, for high $\mathrm{pH}$ values, the negative charges at the surface of the adsorbent increases and consequently the adsorption of $\mathrm{F}^{-}$ ions is deprived. Yang and Dluhy (2002) also showed that the best water defluoridation performance using calcite was obtained for a neutral $\mathrm{pH}$ solution $(\mathrm{pH}=7)$. Following their study on the synthesis of fluoridated water treatment technologies, (Meenakshi and Maheshwari, 2006) concluded that no one process can be used under all conditions; therefore, each technology has its limitations. Consequently, selection of the treatment process should be site specific and based on local needs and initial conditions. In order to propose an appropriate defluoridation technology to the population of the watershed of mayo Tsanaga, in a context where no local technology is yet available, we embark on the design, manufacture and test of drinking water defluoridation unit that is affordable, accessible and easily adoptable by the population using locally available materials (cow bone char). 


\section{MATERIALS AND METHODS}

The prototype of filter constructed was adapted from two (02) existing models: The domestic defluoridation biochar filter proposed by the Inter-Country Centre for Oral Health $(\mathrm{ICOH})$ in Thailand and the domestic defluoridation filter using tiny clay bricks from Sri Lanka (Fawell et al., 2004). Our prototype is of ascending type, this choice was made as it allows a better control of contact time between untreated water and the filter substrate. This time was set to be $60 \mathrm{~min}$ in the present design.

The filtration unit is composed of two (02) compartments, the water tank and the filter (Figure 1). The water tank is connected to the filter using a transparent polyethylene pipe of $20 \mathrm{~mm}$ diameter and $1450 \mathrm{~mm}$ long. The main filter frame consists of a polyvinyl chloride (PVC) pipe of $125 \mathrm{~mm}$ diameter and $1000 \mathrm{~mm}$ height, with a top and bottom cover. The polyethylene pipe from the reservoir enters the filter frame through an opening on the top cover of the filtration column. The latter is guided by a PVC pipe of $25 \mathrm{~mm}$ diameter and $1000 \mathrm{~mm}$ height, mounted at the centre of the filtration column. This $25 \mathrm{~mm}$ PVC pipe is perforated from its lower end with holes of 4-6 $\mathrm{mm}$ diameter on a height of $200 \mathrm{~mm}$. These holes allow water from the tank to flow through the filtering media (Figure 2). The filtering media consists of cow-bone biochar, fine sand and gravel as drainage material. Cow-bones were collected at the slaughter place of the town, these were pyrolysed in a retort kiln at $250{ }^{\circ} \mathrm{C}$ for 4 hours, then in a muffle furnace at $600{ }^{\circ} \mathrm{C}$ for $30 \mathrm{~min}$. The obtained char was crushed and sieved to have particle size ranging within 0.25 and $0.75 \mathrm{~mm}$. Sand and gravel were washed and calibrated before being used. These filtering media were filled in the plastic column separating each other with perforated plastic disks of $115 \mathrm{~mm}$ diameter. The arrangement of the various substrates as well as their thickness and sizes are shown in Figure 2.

In order to test the effectiveness of the filter in the laboratory, we spiked distil water samples with $\mathrm{F}^{-}$ions, then filtered and determined $\mathrm{F}^{-}$ion content after filtration. Spiking was accomplished by diluting ammonium fluoride $\left(\mathrm{NH}_{4} \mathrm{~F}\right) 95 \%$, with known concentrations of distilled water in order to have water samples with 10.20 and $30 \mathrm{mgl}^{-1}$ of $\mathrm{F}^{-}$ion. These concentrations were chosen to mimic the situation in the Mayo Tsanaga river basin where average $\mathrm{F}^{-}$ion concentration of underground water is $16 \mathrm{mg} \mathrm{l}^{-1}$. The mass of ammonium $\mathrm{F}^{-}\left(\mathrm{m}_{1}\right)$ to be used in order to have the desired concentration of $\mathrm{F}^{-}$ions in the solution was estimated using Equation (1).

$\mathrm{m}_{1}=\frac{\mathrm{m}_{2} \times \mathrm{M}_{1}}{\mathrm{M}_{2}} \times \frac{100}{\mathrm{P}}$

Where: $\mathbf{m}_{1}$ : mass of $\mathrm{NH}_{4} \mathrm{~F}, \mathbf{m}_{2}$ : mass of $\mathrm{F}^{-}$, $\mathbf{M}_{1}$ : molar mass of $\mathrm{NH}_{4} \mathrm{~F}, \mathbf{M}_{2}$ : molar mass of $\mathrm{F}^{-}$, p: percentage of purity of $\mathrm{NH}_{4} \mathrm{~F}$.

Quantities of $\mathrm{NH}_{4} \mathrm{~F}$ diluted in 11 and the codes attributed to each water sample are presented in Table 1.

Fluoridated water from the reservoir flows by gravity at the rate of $3.33 \mathrm{lh}^{-1}$ to the bottom of the filtration column, from where it ascends gradually, passing through the different substrates of the filtering media. It is then collected on top of the filtering media via a tap (Figure 1). The adjusted flow corresponds to a retention time of approximately $53 \mathrm{~min}$, close to the $60 \mathrm{~min}$ recommended by (Fan et al., 2003; Nasr, 2014). For each of the 3 concentrations, 3 filtration tests were carried out on 3 separate but identical filtering media. Nine samples of $100 \mathrm{ml}$, coded as A1, A2, A3, $\mathrm{B} 1, \mathrm{~B} 2, \mathrm{~B} 3, \mathrm{C} 1, \mathrm{C} 2$ and $\mathrm{C} 3$ were collected at the outlet for laboratory analysis. Ion chromatography (ICS 1100) was used to determine the concentration of $\mathrm{F}^{-}$ions in samples. $\mathrm{pH}$ of each of these samples was also determined after filtration using a glass electrode $\mathrm{pH}$ meter. Data were analysed using the linear mixed-effects (lme) model of $\mathrm{R}$ software v.3.2 for Windows. This was followed by Tukey HSD test for multiple comparisons. Potential relationships in between assessed parameters was investigated using the Spearman correlation function of R. 


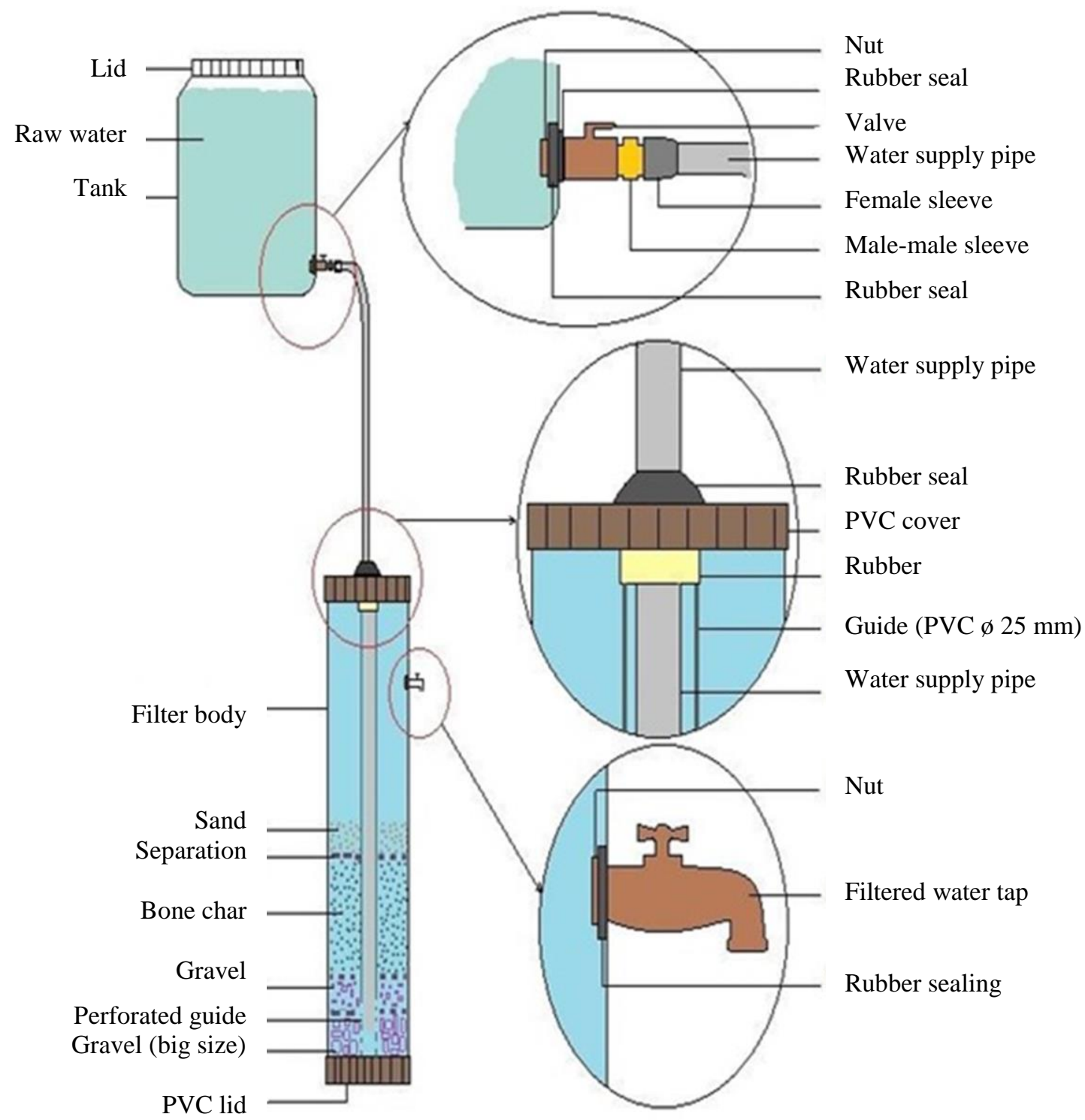

Figure 1: Filter trame.

Table 1: Mass de $\mathrm{NH}_{4} \mathrm{~F}$ to be dissolved in order to have a given concentration of $\mathrm{F}^{-}$.

\begin{tabular}{ccc}
\hline Mass of $\mathbf{N H}_{\mathbf{4}} \mathbf{F}(\mathbf{m g})$ & Concentration of $\mathbf{F}^{-}$ions $\left(\mathbf{m g l}^{-\mathbf{1}}\right)$ & Codes of samples \\
\hline 62 & 30 & $\mathrm{~A}$ \\
42 & 20 & $\mathrm{~B}$ \\
21 & 10 & $\mathrm{C}$ \\
\hline
\end{tabular}




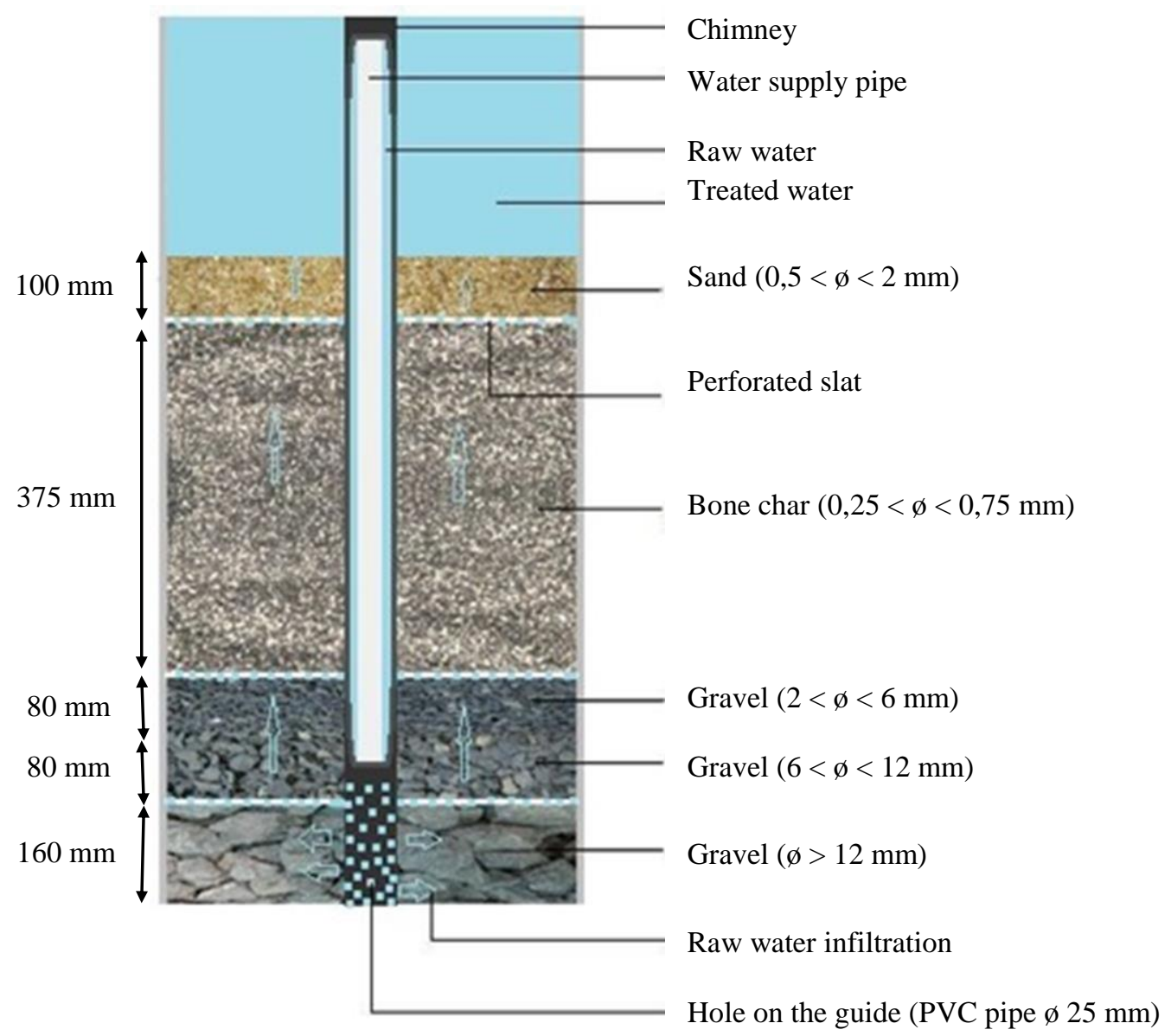

Figure 2: Core filter with different layers.

Table 2: Summary of data collected (mean values and standard deviation of final $\mathrm{F}^{-}$concentration and $\mathrm{F}^{-}$reduction rate; $\mathrm{P}$-values of THSD comparing $\mathrm{B}-\mathrm{A}, \mathrm{C}-\mathrm{A}$ and $\mathrm{C}-\mathrm{B}$ ).

\begin{tabular}{|c|c|c|c|c|c|c|c|}
\hline \multirow[t]{2}{*}{ Sample code } & \multirow{2}{*}{$\begin{array}{l}\text { Initial } \mathrm{F}^{-} \\
\text {concentration } \\
\left(\mathbf{m g l}^{-1}\right)\end{array}$} & \multirow{2}{*}{$\begin{array}{l}\text { Mean final } \mathrm{F}^{-} \\
\text {concentration } \\
\left(\mathrm{mgl}^{-1}\right)\end{array}$} & \multirow{2}{*}{$\begin{array}{l}\text { Standard } \\
\text { deviation }\end{array}$} & \multirow{2}{*}{$\begin{array}{l}\mathrm{F}^{-} \\
\text {reduction } \\
\text { rate }\end{array}$} & \multirow{2}{*}{$\begin{array}{l}\text { Standard } \\
\text { deviation }\end{array}$} & \multicolumn{2}{|c|}{$\begin{array}{l}\text { P-values of TuKeyHSD } \\
\text { test with alpha }=5 \%\end{array}$} \\
\hline & & & & & & B & $\mathbf{C}$ \\
\hline $\mathbf{A}$ & 10 & 0,52 & 0.09 & 94.8 & 0.9 & 0.99 & 0.48 \\
\hline B & 20 & 0.51 & 0.42 & 97.45 & 2.1 & I & 0.50 \\
\hline $\mathbf{C}$ & 30 & 0.26 & 0.07 & 99.1 & 0.2 & l & l \\
\hline
\end{tabular}




\section{RESULTS}

Diagrams of the constructed filter are shown in Figures 1 and 2. Table 2 summarizes the collected data and some results of statistical analysis. Values of $\mathrm{pH}$ ranged from 6.64 to 7.66, these values were not statistically different $(\mathrm{p}=0.55)$. Using Pearson correlation, we noted very poor positive linear relation (0.29) between fluorine reduction rate (FRR) and $\mathrm{pH}$ of water indicating no significant influence of $\mathrm{pH}$ variation in this range on $\mathrm{F}^{-}$ reduction rate. The initial $\mathrm{F}^{-}$concentration (IFC) significantly influenced FRR at 5\% precision interval $(\mathrm{p}=0.02)$, with the highest rate being $99.17 \%$ obtained with initial $\mathrm{F}^{-}$ion concentration of $10 \mathrm{mgl}^{-1}$. The reduction rates obtained in this experiment ranged between $94.8 \%$ and $99.1 \%$. Within the assed range of $10-30 \mathrm{mg} / \mathrm{l}$, the FRR was estimated from IFC using linear regression as shown in equation 2 ; with a determination coefficient of 0.98 . $F R R=101.42-0.225 * I F C$

\section{DISCUSSION}

The effectiveness of the constructed filter to defluoridate water was tested by varying the concentration of fluoride ions in water. The average fluoride reduction rate obtained in this experiment $(97 \%)$ remain relatively high as those obtained by Mjengera and Mkongo (2003) using the bone-char filter developed by Inter-Country Centre for Oral Health (ICOH) in Thailand (99\%). The variation of $\mathrm{pH}$ was not significant and did not significantly influence $\mathrm{F}^{-}$reduction rate, similar results were reported by Nasr (2014) who found that when the $\mathrm{pH}$ of the solution varies between 4.5 and 7.5 , the retention rate of $\mathrm{F}^{-}$ions is almost constant and high. Final $\mathrm{F}^{-}$ concentration obtained were below the recommended range of $\left(1.5-3 \mathrm{mg} \mathrm{l}^{-1}\right)$ in drinking waters (Fawell et al., 2006). Though we obtain a linear relation between fluoride reduction rate and initial fluoride concentration in water with good determination coefficient, we might expect that the form of this relation changes with time as the bonechar become saturated with $\mathrm{F}^{-}$. All the above presented results from the constructed filter are in agreement with the findings in Tanzania, Kenya, Uganda, Ethiopia and South Africa (Dahi, 2016; Fantong et al., 2019) though from different filter designs. Assuming that each person consumes 3 litres of water daily, the constructed filter has the capacity of supplying drinkable water to at least 20 people daily with an initial fluoride concentration in water ranging from 10 to $20 \mathrm{mgl}^{-1}$. The construction cost for this filter was estimated to be ten thousand franc cfa (17 US\$). This cost was judged affordable by each family as a medium scale investment for this appropriate technology, mainly in the situation whereby no such specific filter is available in the local market.

\section{Conclusion}

High fluoride concentration in underground water remain a serious concern in many parts of the word and in some cases, inhabitants of these regions might solely rely on this water for their feed. In this research work, we successfully design, construct and test a family scale water filter to mitigate fluoride health risks facing population in the North Cameroon in particular and in low income countries in general. The proposed filter efficiently reduced $\mathrm{F}^{-}$ion concentration from contaminated water, up to a safer level. Based on the obtained results, this filter could be used by the local population as no other one is actually available in the local market. However, the test of the filter for a longer period to confirm the estimated breakeven point of three months before biochar replacement in the filter remain a prerogative before the filter could be recommended for general use. This assessment will be tackled in the next phase of this study. This appropriate technology could actually help the local population improve on their resilience to health hazards associated with the consumption of poor drinking water quality.

\section{COMPETING INTERESTS}

The authors declare that they have no competing interests.

\section{AUTHORS' CONTRIBUTIONS}

All authors contributed to the conception and design, material preparation, data collection and analysis. 


\section{REFERENCES}

Ayoob S, Gupta AK. 2006. Fluoride in Drinking Water: A Review on the Status and Stress Effects. Critical Reviews in Environmental Science and Technology, 36(6): $433-437 . \quad$ DOI: https://doi.org/10.1080/10643380600678112.

Bhatnagar A, Kumar E, Sillanpää M. 2011. Fluoride removal from water by adsorption-A review. Chemical Engineering Journal, 171(3): 811-840. DOI http://dx.doi.org/10.1016/j.cej.2011.05.028.

Fan X, Parker DJ, Smith MD. 2003. Adsorption kinetics of fluoride on low cost materials. Water Research, 37(20): 4929-4937.

DOI: https://doi.org/10.1016/j.watres.2003.08.014

Fantong J, Satake WY, Ayonghe H, Aka FT, Asai K. 2008. Hydrogeochemical controls and usability of groundwater in semi-arid Mayo Tsanaga River Basin, Far North Province. Cameroon. Environ. Geol., 58: 1281-1293. DOI: https://doi.org/10.1007/s00254-0081629-x

Fantong J, Satake WY, Ayonghe H, Suh SN, Adelana CE, Fantong SMA, Banseka EBS, Gwanfogbe HS, Woincham CD, Uehara LN, Zhang J. 2010. Geochemical provenance and spatial distribution of fluoride in groundwater of Mayo Tsanaga River Basin, Far North Region, Cameroon: implications for incidence of fluorosis and optimal consumption dose. Environ. Geochem Health, 32: 147-163. DOI: https://doi.org/10.1007/s10653009-9271-4.

Fawell J, Bailey K, Chilton J, Dahi E, Fewtrell L, Magara Y. 2004. Fluoride in Drinkingwater: Background document for development of WHO Guidelines for Drinking-water Quality. World Health Organization, WHO/SDE/WSH/03.04/96. $17 \mathrm{p}$.

Ghosh S. 2016. Methods for Defluorodation Techniques Employed in Potable Water Treatment: An Overview. Journal of Chemistry, Physics, Mathematics \& Applied Sciences (ASIO-JCPMAS), 1(1): 12-16. DOI: https://doi.org/03.201626169319.

Goyit MP, Solomon OA, Kutshik RJ. 2018. Distribution of fluoride in surface and ground water: a case study of Langtang North, Plateau State, Nigeria. Int. J. Biol. Chem. Sci., 12(2): 1057-1067. DOI: 10.4314/ijbcs.v12i2.33

Grützmacher G, Rustler M, Hannappel S, Sauer U. 2013. Geogenic groundwater contamination: definition, occurrence and relevance for drinking water production. Zbl. Geol. Paläont. Teil I, Jg. Heft, 1: 69-75. http://www.hydor.de/downloads/PDF/ve roeffentlichungen2015/

L'Hôte Y, Mahé G, Somé B, Triboulet JP. 2002. Analysis of a Sahelian annual rainfall index from 1986 to 2000; the drought continues. Hydrological Sciences Journal, 47(4): 563-572. DOI: https://doi.org/10.1080/02626660209492 960

Meenakshi, Maheshwari RC. 2006. Fluoride in drinking water and its removal. Journal of Hazardous Materials, 137(1): 456-463. DOI:

https://doi.org/10.1016/j.jhazmat.2006.0 2.024

Mjengera H., Mkongo G. 2003. Appropriate deflouridation technology for use in flourotic areas in Tanzania. Physics and Chemistry of the Earth, 28(20-27): 10971104.

DOI: https://doi.org/10.1016/j.pce.2003.08.030

Nasr BA. 2014. Performances des procédés physico-chimiques et membranaires pour l'élimination des ions fluorure dans les eaux de forage : application aux eaux tunisiennes. Génie des procédés. Thèse de doctorat, Université Claude Bernard Lyon I, 105p.

Swarnakar AK, Choubey S, Sar SK. 2007. Defluoridation of Water by Various Techniques- A Review. International Journal of Innovative Research in Science, Engineering and Technology, 5(7): $\quad$ 13174-13178. DOI: https://doi.org/10.15680/IJIRSET.2016.0 507192

Yang CL, Dluhy R. 2002. Electrochemical generation of aluminum sorbent for fluoride adsorption. Journal of Hazardous Materials, 94(3): 239-252. DOI: https://doi.org/10.1016/S03043894(02)00066-3 